\title{
Effect of Moderate Excess Methionine on Growth, Feed Intake and Utilization of Energy and Nitrogen in Chicks
}

\author{
Hiroshi Ueda and Hiro-omi Yokota \\ Faculty of Agriculture, Nagoya University, Nagoya-shi 464
}

\begin{abstract}
It was reported by several workers ${ }^{1,2,3}$ that dietary excess methionine adversely affected the growth rate of chicks. The mechanism by which body weight gain of chicks fed the methionine excess diet was decreased, however, has not been established. UEDA and TASAKI $^{1}$ reported that the addition of $2.7 \%$ DL-methionine to the methionine adequate diet resulted in not only the severe depression in body weight gain and feed intake but also the decrease in energy and nitrogen utilization. Since the growth retardation of the chicks receiving the methionine excess diet was dependent on the levels of methionine added to the diet ${ }^{2}$, the present experiment was designed to study the effect of moderate excess methionine on growth, feed intake and efficiencies of energy and nitrogen utilization.
\end{abstract}

\section{Experimental}

Day-old Single Comb White Leghorn male chicks were raised on a commercial chick starter for 7 days. On day 8 , the chicks were individually weighed after 3 -hour fasting and assigned to 12 groups of 2 chicks each and 1 group of 5 chicks so that the average starting body weight was similar for each group. Six replicates of 2 chicks each were fed each of the control and methionine excess diets from day 8 to day 20, and 5 chicks of the last group were killed with ethyl ether to determine the initial body composition. The composition of the control diet used here was as follows (in percent): isolated soybean protein, 25.78; cornstarch, 40.64; glucose, 20.00; corn oil, 4.00; cellulose, 3.00; mineral mixture ${ }^{4}, 5.63$; vitamin mixture ${ }^{5)},+(0.75 \mathrm{~g} / \mathrm{kg}$ diet $) ;$ choline chloride, 0.20 ; L-methionine 0.50 ; and glycine 0.25 . This diet contained $21.5 \%$ of crude protein and $0.81 \%$ of sulfur-containing amino acids. The methionine excess diet was made by adding $1.0 \% \mathrm{~L}$-methionine to the control diet at the expense of cornstarch.

Feed and water were available freely throughout the 12-day experimental period. Body weight change and feed intake were recorded every other day, and excreta were collected in a tray containing $100 \mathrm{ml}$ of $0.1 \%$ sulfuric acid during the last 2 days of the experimental period. On day 20, the chicks were weighed after 3 -hour fasting and killed with ethyl ether to prevent the loss of blood.

Whole carcasses were frozen and minced with a meat grinder (Onoue Chopper No. 2, Onoue Co., Nagoya). The minced carcasses were refrozen with dry ice and minced again. This procedure was repeated twice and dried at $55^{\circ} \mathrm{C}$ for 48 hours. Excreta 
were homogenized with an electric blender (Osterizer cycle blend, Oster Co., Milwaukee) after diluting to appropriate volume, and then dried at $55^{\circ} \mathrm{C}$ for 24 hours. Nitrogen in the diets, excreta and carcasses was determined by a Kjeldahl procedure and carcass protein was defined as nitrogen $x$ 6.25. Carcass fat was extracted by ethyl ether using a Soxhlet apparatus and determined gravimetrically. Gains in fat and protein during the experimental period were estimated by reducing the initial values of body composition from the final ones on day 20. Average initial body weight of the chicks on day 8 was $78.0 \mathrm{~g}$ and they contained $5.8 \mathrm{~g}$ and $12.5 \mathrm{~g}$ of fat and protein, respectively. Energy gain was calculated from the gains in fat and protein using the values of $39.12 \mathrm{~kJ}$ $(9.35 \mathrm{kcal}) / \mathrm{g}$ and $23.68 \mathrm{~kJ}(5.66 \mathrm{kcal}) / \mathrm{g}$, respectively ${ }^{6}$. Caloric values of the diets and excreta were measured using an automatic bomb calorimeter (Shimazu CA-3, Shimazu Co., Kyoto). Metabolizable energy values were determined according to the method of Hill and ANDERson?".

\section{Results and discussion}

The results of the present experiment were summarized in table 1. Additional supplementation of $1.0 \% \mathrm{~L}$-methionine to the control diet significantly decreased body weight gain by $12.2 \%(\mathrm{P}<0.05)$. Feed intake of the chicks fed the methionine excess diet was also decreased by $9.4 \%(\mathrm{P}<0.01)$. In the previous experiment ${ }^{11}$, the chicks fed the methionine excess diet containing additional $2.7 \%$ methionine decreased body weight gain and feed intake by 64.7 and $39.3 \%$, respectively. The observation that the depression in body weight gain and feed intake in the present experiment was much less than that observed in the previous experiment ${ }^{11}$ was attributed to the supplemented methionine

Table 1. Effects of moderate excess methionine on body weight gain, feed intake, efficiency of feed utilization, body composition, gains in fat, protein and energy, and utilization of energy and nitrogen (Mean \pm SEM).

\begin{tabular}{lcc} 
& Control & Met excess \\
\hline Body weight gain (g/chick) & $103.0 \pm 3.8$ & $90.4 \pm 2.2^{*}$ \\
Feed intake (g/chick) & $194.6 \pm 3.8$ & $176.4 \pm 2.3^{* *}$ \\
Efficiency of feed & & \\
utilization (g/100 g) & $52.9 \pm 1.4$ & $51.2 \pm 1.1$ \\
Body composition & & \\
Moisture (\%) & $70.4 \pm 0.1$ & $70.4 \pm 0.2$ \\
Protein (\%) & $17.9 \pm 0.3$ & $17.9 \pm 0.2$ \\
Fat (\%) & $8.1 \pm 0.2$ & $7.3 \pm 0.3$ \\
Gain & $9.0 \pm 0.8$ & $6.8 \pm 0.6^{*}$ \\
Fat (g/chick) & $20.0 \pm 0.7$ & $17.7 \pm 0.4^{*}$ \\
Protein (g/chick) & $823.4 \pm 40.2$ & $686.2 \pm 26.8^{* *}$ \\
Energy (kJ/chick) & & \\
Utilization & $31.7 \pm 1.3$ & $28.6 \pm 1.0^{*}$ \\
Energy (\%) & $47.7 \pm 1.1$ & $45.3 \pm 1.0$ \\
Nitrogen (\%) &
\end{tabular}

*, ** Significantly different at $\mathrm{P}<0.05$ and $\mathrm{P}<0.01$, respectively. 
level as reported by GRIMINGER and FISHER ${ }^{2}$. Furthermore, efficiency of feed utilization was significantly decreased by feeding the severe methionine excess diet in the previous experiment $^{1}$. In the present experiment, however, the efficiency of feed utilization of the chicks fed the moderate amount of excess methionine was almost the same as that of the control chicks. This result indicated that the growth retardation of the chicks fed the moderate methionine excess diet primarily resulted from the depression in feed intake.

Protein and moisture contents in the carcass were not changed by feeding the methionine excess diet, but fat content of the chicks fed the methionine excess diet tended to decrease, though statistical significance was not observed. This result was essentially the same as the result of the previous experiment ${ }^{11}$, regardless of severity of excess methionine. The chicks fed the methionine excess diet retained significantly less fat and protein than those fed the control diet $(\mathrm{P}<0.05)$. Consequently, these chicks retained $16.7 \%$ less energy than the control chicks $(\mathrm{P}<0.01)$.

Metabolizable energy value was not influenced by the methionine level in the diet as reported previously ${ }^{1,6)}$, being $13.35 \pm 0.08$ and $13.51 \pm 0.04 \mathrm{~kJ} / \mathrm{g}$ for the control and methionine excess diets, respectively, and the metabolizability of dietary energy was calculated as $81.1 \%$ for both groups. Therefore, metabolizable energy consumption of the chicks fed the control and methionine excess diets for 12-day experimental period was in parallel with the feed intake of the respective group. In the view of the energy utilization, expressed as a ratio of retained energy to metabolizable energy consumption, the chicks fed the methionine excess diet utilized consumed metabolizable energy less efficiently than those fed the control diet $(\mathrm{P}<0.05)$. The decreased energy utilization was also observed in the previous experiment ${ }^{11}$ and the depression rate was greater than that presented here. Whereas, the chicks fed the moderate excess methionine utilized dietary nitrogen as efficiently as those fed the control diet as shown in table 1 . This result was distinct from that reported previously ${ }^{1)}$ which showed that the efficiency of nitrogen was markedly decreased by feeding the severe methionine excess diet.

From the results observed in the present and the previous experiments ${ }^{1}$, it appeared that the efficiencies of energy and nitrogen utilization were modified by the methionine level supplemented excessively. These results suggest that the degree of excess methionine plays an important role in energy and nitrogen metabolism.

\section{Summary}

In order to study the effect of moderate excess methionine on growth, feed intake and efficiencies of energy and nitrogen utilization in chicks, 8-day-old Single Comb White Leghorn chicks were fed the methionine adequate control and moderate methionine excess diets for 12-day experimental period. Body weight gain and feed intake of the chicks fed the methionine excess diet were significantly decreased, whereas efficiency of feed utilization was not affected by feeding the methionine excess diet. Body composition was not different between both groups, but the chicks fed the methionine excess diet retained significantly less fat, protein and energy than those fed the control diet. 
Although metabolizability of dietary energy was not altered by excess methionine, the efficiency of metabolizable energy utilization was decreased. Whereas, nitrogen utilization was not depressed by feeding the methionine excess diet.

\title{
Acknowledgement
}

The authors wish to express their hearty thanks to Dr. I. TASAKI, Professor of Animal Nutrition, Nagoya University for his advice.

\section{Literature}

1) Ueda, H. and I. Tasaki: Japan. Poultry Sci., 14, 138, 1977.

2) Griminger, P. and H. Fisher: Poultry Sci., 47, 1271, 1968.

3) Katz, R.S. and H. A. BAKER: J. Nutr., 105, 1168, 1975.

4) Nesheim, M.C., J.D. Garlich and D. T. Hopkins: J. Nutr., 78, 89, 1962.

5) Velu, J.D., D. H. BaKer and H. M. ScotT: J. Nutr., 101, 1249, 1971.

6) Sнолі. K., K. ТотsuкA and M. Tajima: Jap. J. Zootech. Sci., 37, 246, 1966.

7) Hill, F.W. and D. L. Anderson: J. Nutr., 64, 587, 1958.

\section{ヒナの成長， 飼料椇取量およびェネルギーと窒素の \\ 利用に及ぼす軽度のメチオニン過剩飼料給与の影響}

\author{
上间博史・横田浩臣 \\ 名大農学部 名古屋市 464
}

メチオニン過剩飼料がヒナのエネルギーおよび窒素の 利用性を低下させることは前報1で報告したが，過剩の 程度は増体量の減少率が対照の $65 \%$ という極端なもの であった。そこで本実験では軽度のメチオニン過剩飼料 を用いて, ヒナの増体量, 飼料摂取量および飼料の土ネ ルギーと窒素の利用に及ぼす影響を調べた。供試ヒナは 体重の均一な 8 日齢の白レグ雄を用い, 1 群 2 羽の 12 群 に分け，それぞれ6群ずつに対照䬲料とメチオニン過剩 飤料安給しょして 12 日間飼育した。対照飼料の組成は飤 料 $1 \mathrm{~kg}$ 当り, 大豆螢白質 $257.8 \mathrm{~g}$, コーンスターチ $406.4 \mathrm{~g}$, グルュース $200 \mathrm{~g}$, ニーンオイル $40 \mathrm{~g}$, 七ル口 一大 $30 \mathrm{~g}$, ビタミン・ミネラル混合物 $58.3 \mathrm{~g}$, L-メチ才 ニン $5.0 \mathrm{~g}$ およびグリシン $2.5 \mathrm{~g}$ とした。またメチオ二 ン過剩飼料は対照飼料に $1.0 \%$ ○一メチオニンをコーン スターチと置きかえて添加した。飼育試験終了後, ヒナ は屠体分析に供した。

ヒナの増体重および飼料搷取量はメチオニン過剩飼料
の給与によって有意に減少し，減少率はそれぞれ対照区 の12\%および $9 \%$ あった。しかし飼料効率には差は認 められなかった。屠体成分は脂肪含量に減少の傾向がみ られたが有意な养ではなかった。また蛋白質および水分 含量にも养はなかった。しかしメチオニン過剩飼料を掑 取したヒナの脂肪，蛋白質およびェネルギーの蓄積量は 增体重の受を反映して有意に低下した。飤料ェネルギー の代謝率注画区に抢いて产はなかったが，代謝エネルギ 一の利用性はメチオニン過剩飼料を提取したヒナでは们 意に減少した。しかし飤料の窒素の利用性はメチオニン 過剩で影響を受けなかった。

軽度のメチオ二ン過剩䬲料の給与により，ヒナの増体 重打よび泀料摂取星の減少の程度は解朝1)と比較して軽 減され，また飼料のエネルギーおよび窒素の利用性の低 下も緩和された。

（家禽会誌，14，236～239，1977） 